\author{
PIOTR KŁOSIŃSKI \\ Katedra Ekologii i Biogeografii \\ Wydziat Nauk Biologicznych $i$ Weterynaryjnych \\ Uniwersytet Mikołaja Kopernika \\ Lwowska 1, 87-100 Torun \\ E-mail: peter.klosinski1995@gmail.com
}

\title{
ZNACZENIE SUBSTANCJI ALARMOWYCH W KOMUNIKACJI CHEMICZNEJ RYB
}

\section{KOMUNIKACJA CHEMICZNA ORGANIZMÓW}

Komunikacja zwierzat jest zjawiskiem intuicyjnie prostym do zrozumienia, ale trudnym do jednoznacznego zdefiniowania (REK 2010). Funkcjonuje wiele definicji, wyjaśniających komunikację zarówno w sposób bardzo szeroki, jak i bardzo wąski (KULCZYCKI 2012). Najogólniej rzecz biorąc, komunikacja to zjawisko, w którym dokonuje się transfer informacji między nadawca a odbiorcą. Dodatkowo, transfer musi odbywać się przez tzw. kanał, czyli zbiór warunków środowiskowych potrzebny do udanego przesyłu informacji (TROJAN 2013). Z komunikacja zwiazane sa takie pojęcia jak sygnał (ang. signal) i wskazówka (ang. cue). Sygnał to element komunikacji intencjonalnej, będacy nośnikiem informacji pomiędzy nadawca i odbiorca, ale również służący osiągnięciu określonej korzyści przez nadawcę. Z kolei wskazówka przenosi informacje będące efektem ubocznym zachowania nadawcy i nie ma nic wspólnego $z$ celowościa informowania (REK 2010). $Z$ uwagi na to, że termin "sygnał chemiczny” jest od lat używany w literaturze przedmiotu $\mathrm{w}$ kontekście reakcji alarmowych ryb (JACHNER 1999, PIJANOWSKA 1999), zastosowano go także w niniejszej pracy, $z$ zastrzeżeniem jednak, że nie ma on tutaj zwiazku $z$ intencjonalnym przekazem informacji.

Behawior to cały kompleks obserwowalnych, rejestrowalnych lub mierzalnych czynności żywego zwierzęcia w odpowiedzi na dany czynnik/bodziec odbierany $z$ otoczenia lub wnętrza organizmu (KeENLEyside 1979, KOKOCIŃSKA i KALETA 2015). Behawior zwierzat modyfikowany jest m.in. przez zwiazki zaklasyfikowane do grupy tzw. semiozwiązków (gr. semio, sygnał), czyli substancji bioracych udział w porozumiewaniu się organizmów (KATKOWSKA 2013). Historycznie wszystkie formy informacji chemicznych były uważane za feromony (SMITH 1992, WISENDEN i współaut. 1994). Jednak rozwój badań $\mathrm{w}$ tej dziedzinie przyniósł większą kontrolę nad wykorzystaniem terminów. Słowo „feromon" pochodzi z języka greckiego, w którym pherein to przekazywać, a hormao - pobudzać. Nazwa ta została po raz pierwszy zaproponowana przez KARLSONA i LÜSCHERA w 1959 r. W przeciwieństwie do hormonów, które oddziałuja na komórki czy tkanki tego samego organizmu, feromony pełnia funkcje związków sygnałowych w komunikowaniu się różnych organizmów, niekoniecznie należacych do tego samego gatunku (ANTKIEWICZ i współaut. 2008).

Komunikacja chemiczna jest jedna $z$ najstarszych ewolucyjnie form komunikacji między żywymi organizmami. Zagadnienie to od dawna (co najmniej kilkaset lat) budzi zainteresowanie wśród badaczy. Świadcza o tym badania następujących autorów: Charles Butler (1609), Charles Darwin (1871), Jean Henri Fabre (1879), Albrecht Bethe (1932), Adolf Butenandt (1959). Historia poznania zjawiska komunikacji chemicznej rozpoczęła się od owadów (WYATT 2009). Organizmy wodne często do komunikacji wykorzystuja sygnały chemiczne (BRÖNMARK i HANSSON 2000). U ryb pośredniczą one we wszystkich 
podstawowych funkcjach życiowych: rozrodzie, lokalizacji pokarmu, unikaniu drapieżników czy orientacji w przestrzeni (LILEY 1982). Na przykład rozpoznawanie za pomoca substancji chemicznych osobników spokrewnionych i odróżnianie ich od niespokrewnionych zapobiega chowom wsobnym, obniżajacym sukces ewolucyjny (BRÖNMARK i HANSSON 2000).

Pionierem badań nad komunikacją chemiczna ryb za pomoca substancji alarmowych był Karl von Frisch, który w 1938 r. udokumentował uwalnianie substancji alarmowych przez zranione strzeble potokowe Phoxinus phoxinus (VON FRISCH 1938). „Reakcja strachu" (ang. fright reaction, niem. Schreckreaktion) u ryb została wykryta niemal przez przypadek. Von Frisch, prowadzac obserwacje behawioralne tuż po oznakowaniu niektórych osobników przez delikatne nacięcie skóry, zauważył nerwowe pływanie ławicy (PFEIFFER 1963). Najprawdopodobniej był to efekt substancji alarmowej (niem. Schreckstoff - substancja paniki), która jako nośnik informacji o niebezpieczeństwie, czyli przede wszystkim o atakującym drapieżniku, powoduje powszechną reakcję wśród potencjalnych ofiar (JACHNER 1999).

Skóra ryb, a konkretnie warstwa epidermalna ryb, posiada ogromna liczbę wyspecjalizowanych komórek, tzw. club cell, produkujacych substancję alarmowa (Ryc. 1). Komórki te nie maja ujścia na zewnatrz skóry. Posiadaja dużą cytoplazmę wypełnioną pęcherzykami i centralne jądro. Dodatkowo sa otoczone warstwa mniejszych komórek i znajduja się tuż poniżej najbardziej zewnętrznej warstwy nabłonka (JESUTHASAN i MATHURU 2008). Substancja alarmowa jest uwalniana do środowiska tylko w wyniku przerwania błon komórkowych podczas ura-

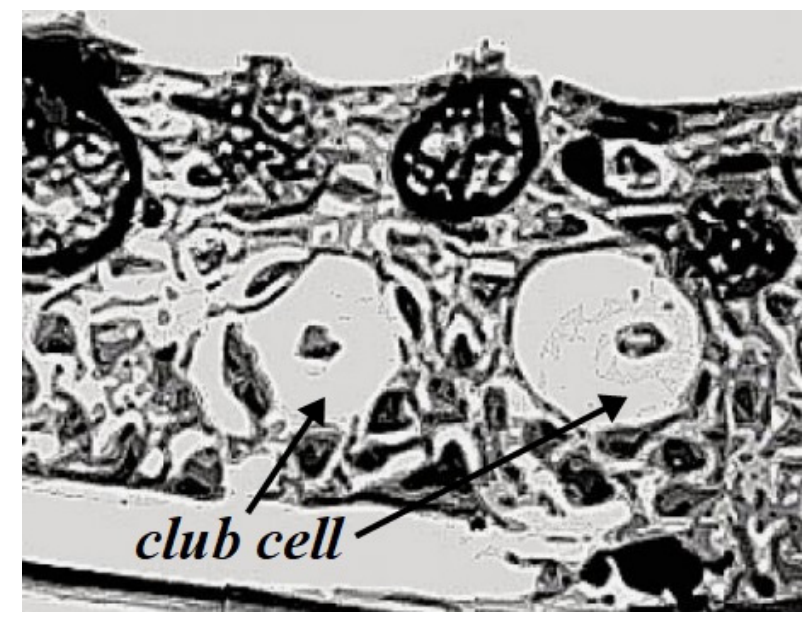

Ryc. 1. Komórki substancji alarmowej (tzw. club cell) w warstwie epidermalnej skóry ryb (CHIVERS i współaut. 2007, zmodyfikowana). zu fizycznego (otarcia badź zranienia powierzchni ciała), co najczęściej utożsamia się $z$ atakiem drapieżnika (WYATT 2003). Ponad $70 \%$ gatunków ryb słodkowodnych wykrywa obecność drapieżnika poprzez odbiór substancji alarmowej $z$ club cells (NELSON 1984, JACHNER 1999). Ryby te posiadaja komórki typu club cells (PFEIFFER 1977), przy czym reakcja alarmowa notowana jest także u gatunków ryb, u których nie stwierdzono tego typu komórek (patrz rozdz. Reakcje behawioralne indukowane przez substancje alarmowe).

Rozpoznawanie obecności drapieżników za pomoca związków chemicznych uwalnianych do środowiska występuje nie tylko u ryb. Obserwowane jest powszechnie $u$ innych kręgowców (z wyjątkiem ptaków) (WELDON 1990, NORDELL 1998). Zjawisko to występuje pospolicie również u bezkręgowców (BUTENANDT i współaut. 1959, GLIWICZ 1986, JERMACZ i współaut. 2017). Zapach ryb planktonożernych i bezkręgowców drapieżnych indukuje mechanizmy obronne u zwierzat planktonowych, m.in. zmianę kształtu ciała, migracje pionowe czy krótszy cykl życiowy (GLIWICZ 1986). Komunikację chemiczna odnotowano też u roślin (HEIL 2009) i bakterii (WINANS i BASSLER 2008, MATEJCZYK i SUCHOWIERSKA 2011). Rośliny wykorzystuja lotne zwiazki organiczne uwalniane przez inne rośliny w wyniku ataku roślinożerców. Dzięki temu te niezaatakowane moga odpowiednio zmodyfikować swój „fenotyp obronny" (HEIL 2009). Z kolei bakterie korzystaja $z$ tzw. quorum sensing, czyli zjawiska chemicznego porozumiewania się, polegającego na syntetyzowaniu i wydzielaniu do środowiska cząstek sygnałowych, bioracych udział w procesach fizjologicznych (MATEJCZYK i SUCHOWIERSKA 2011).

\section{KOMUNIKACJA CHEMICZNA RYB A DRAPIEŻNICTWO}

Drapieżnictwo jest jednym $z$ najsilniejszych czynników kształtujących relacje między zwierzętami $z$ kolejnych poziomów troficznych. Ryby sa znane ze zmiany swojego behawioru w odpowiedzi na obecność drapieżników (Lima i Dill 1990). W wyniku presji drapieżnictwa ofiary wykazują różne strategie obronne, m.in. w zachowaniu, morfologii czy historii życia na poziomie osobniczym bądź populacyjnym (SiH 1987, LIMA i DILL 1990, SiH i WoOster 1994, Chivers i SMith 1998). Ekspozycja ofiar na drapieżnika indukuje u tych pierwszych stres (CLINCHY i współaut. 2013). Ma on na celu zwiększenie szans przeżycia, jest jednak reakcja wysoce kosztowna, modyfikująca behawior. Poza tym, w tego typu sytuacjach streso- 

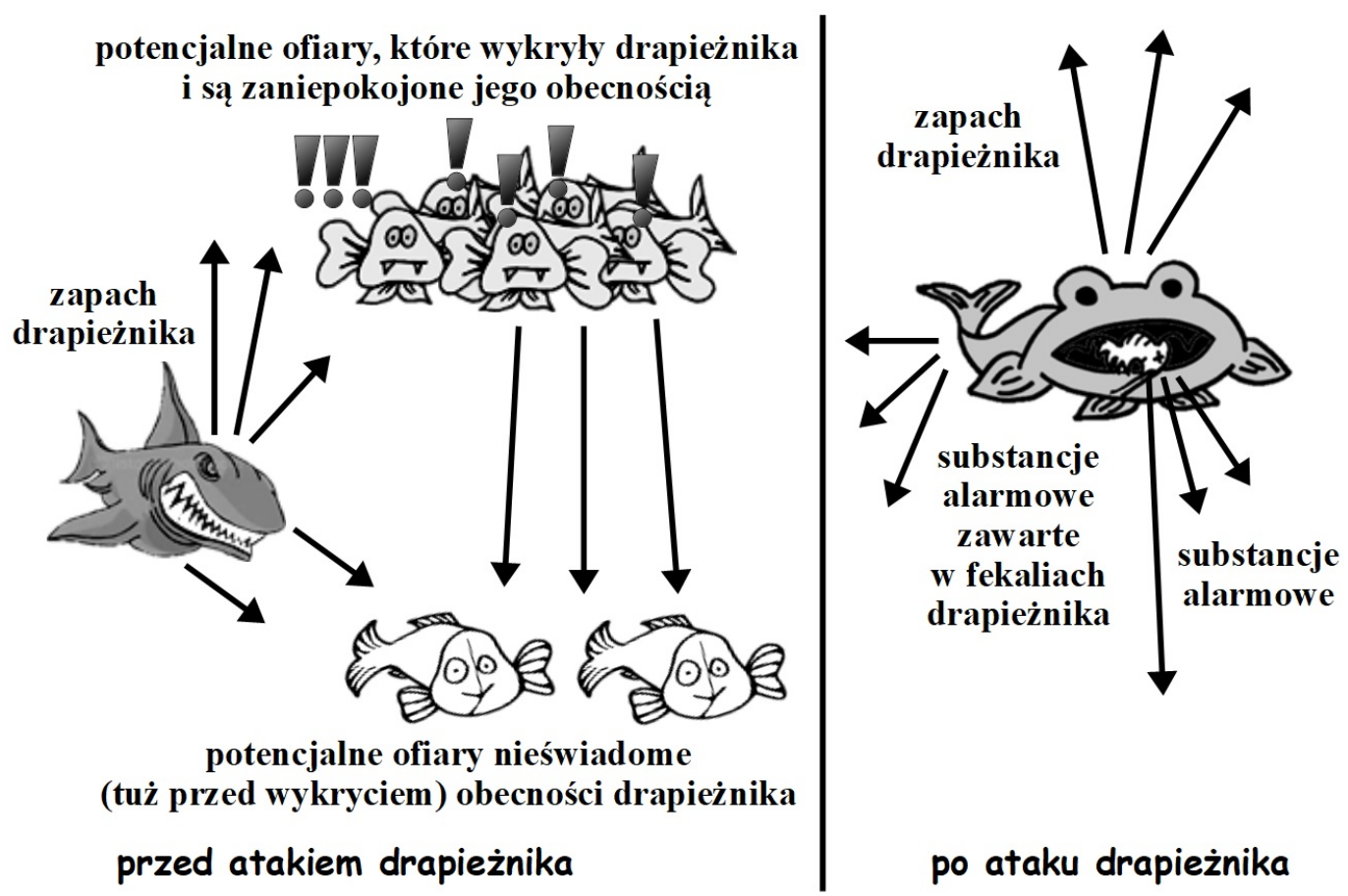

\section{po ataku drapieżnika}

Ryc. 2. Sygnały chemiczne świadczące o obecności drapieżnika w środowisku (strzałka oznacza emitowanie sygnału chemicznego).

wych wiele organizmów ponosi też koszty $z$ powodu ograniczenia efektywności zdobywania pokarmu, co ma negatywne przełożenie na wzrost i rozmnażanie, czyli dostosowanie (ang. fitness) (ADLER i HARWELL 1990).

Zwierzęta stanowiące ofiary w łańcuchu pokarmowym sa zdolne do oceny ryzyka spotkania drapieżnika, kierujac się dostępnymi sygnałami w środowisku. Moga być to sygnały wzrokowe, mechaniczne, elektryczne albo chemiczne (MIRzA i CHIVERS 2001). Poleganie na samych sygnałach wzrokowych w kontekście wykrywania drapieżników może być niewystarczajace, szczególnie wobec ryb polujacych na swoje ofiary $Z$ ukrycia. $Z$ kolei zdolność do elektrorecepcji, polegającej na odbiorze $z$ otoczenia bodźców elektrycznych emitowanych przez różne organizmy, występuje tylko u kilku gatunków ryb, co sprawia, że nie jest to narzędzie powszechne i często wykorzystywane w świecie przyrody (CRAMPTON 2019). Odbieranie sygnałów mechanicznych linią boczna także jest zawodne w sytuacji, gdy drapieżnik nie wykonuje żadnych ruchów. $Z$ kolei percepcja sygnałów chemicznych pozwala zdobyć informacje nie tylko o istnieniu, ale i o stopniu zagrożenia (JACHNER 1999). Dodatkowo, woda nie jest dobrym nośnikiem dla większości sygnałów $z$ powodu małej przenikalności światła i dużej gęstości ośrodka. Sygnalizacja chemiczna daje hydrobiontom możliwość przeciwstawienia się tym ograniczeniom i stąd ma pierwszorzędne znaczenie (SMITH 1992, ANTKIEWICZ i współaut. 2008). Dzięki niej ofiara nie musi zobaczyć drapieżnika, aby zareagować zmiana zachowania (SMITH 1992). Sygnałami chemicznymi świadczacymi o obecności drapieżnika, jak pokazano na Ryc. 2, sa związki pochodzace od drapieżnika (kairomony, czyli zapach drapieżnika), od innych potencjalnych ofiar, które wykryły drapieżnika i sa zaniepokojone jego obecnością, ale jeszcze nie odniosły obrażeń (ang. disturbance cues), oraz tzw. substancje alarmowe uwalniane $\mathrm{w}$ trakcie $\mathrm{i}$ po ataku drapieżnika przez zranione ofiary (ang. damage-released chemical alarm cues), jak również $z$ fekaliów ryb drapieżnych jako wynik trawienia ofiar (ang. dietary alarm cues) (WISENDEN 2015).

Komunikacja chemiczna ma zasadnicze znaczenie dla przetrwania i reprodukcji ryb (JESuTHASAN i MATHURU 2008, CHUNG-DAVIDSON i współaut. 2010). Wymienione substancje informujące o obecności drapieżnika sa niezawodnie skorelowane $z$ aktywnie żerującym drapieżnikiem i wskazują ofiarom bezpośrednie ryzyko drapieżnictwa (CHIVERS i SMITH 1998, WISENDEN 2003, FERRARI i współaut. 2010). Ryby potrafiace wykrywać i interpretować substancje chemiczne informujace o drapieżnictwie, w tym substancje alarmowe, sa w stanie rozpoznać stopień zagrożenia drapieżnictwa przez ocenę ich koncentracji w wodzie (SMITH 1992). Odpowiedź behawioralna ryb na substancję alarmowa od innych osobników własnego gatunku jest uwarunkowana genetycznie, co oznacza, że 
wykazuja ja też osobniki naiwne, czyli takie, które wcześniej nie miały $\mathrm{w}$ swoim życiu kontaktu z drapieżnikiem (PFEIFFER 1963, JACHNER 1999).

\section{CHEMORECEPCJA U RYB}

Chemorecepcja to proces, w którym organizmy reaguja na bodźce chemiczne ze środowiska. U kręgowców odpowiadaja za nia zmysły smaku i węchu (SMITH 1985). Zdolność chemosensoryczna większości ryb jest bardzo wysoko rozwinięta. $Z$ pięciu podstawowych kategorii smakowych, na które człowiek reaguje, ryby prawdopodobnie reaguja tylko na dwie: kwaśny i gorzki (HARA 1994). Ryby maja aż pięć różnych układów chemosensorycznych: (1) węch, (2) kubki smakowe z komórkami receptorowymi, (3) pojedyncze komórki smakowe, (4) wolne zakończenia nerwowe oraz (5) linię boczna (SMITH 1985). VON FRISCH (1941) dostarczył dowodów, że system węchowy odgrywa jednak najważniejsza rolę $\mathrm{w}$ odpowiedzi alarmowej ryb. W badaniach prowadzonych na strzeblach potokowych wykazał, że substancja alarmowa jest wykrywana przez zmysł węchu, natomiast zmysł smaku nie jest zaangażowany $\mathrm{w}$ tej reakcji. Kiedy oba nerwy odpowiadajace za smak i zapach zostały zniszczone, reakcja była całkowicie utracona. Po usunięciu nerwu węchowego, zwierzęta nie wykazywały reakcji na zadana substancje alarmową (PFEIFFER 1963). Ściślej rzecz ujmują, ryby wykrywaja substancje alarmowa za pomoca opuszki węchowej znajdującej się w kresomózgowiu (VON FRISCH 1941, HAMDANI i współaut. 2000, HAMDANI i Døving 2003, MATHURU i współaut. 2012).

System alarmowy ryb składa się $z$ dwóch komponentów: morfologicznego, czyli obecności komórek produkujacych substancję alarmowa (ang. club cells), i behawioralnego - zdolności do wykrywania, a następnie reagowania na odebrany sygnał chemiczny (SмiтH 1977). Mimo że neurony węchowe ryb wydaja się być specjalnie dostrojone do substancji alarmowej $z$ uszkodzonego naskórka osobników własnego gatunku, to również w mniejszym stopniu reaguja one na substancje alarmowe osobników obcego gatunku (WISENDEN 2015). Istnieje ogólne przekonanie, że często występuja wrodzone reakcje międzygatunkowe na substancje alarmowe osobników obcego gatunku wśród blisko spokrewnionych gatunków, podczas gdy rozpoznawanie substancji od daleko spokrewnionych musi zostać poznane i nauczone przez ryby (POLLOCK i CHIVERS 2004). Ofiary często reagują na substancje alarmowe pochodzace od innych gatunków (MATHIS i SMITH 1993a; ChIVers i współaut. 1995a, b; BROwN i GODIN 1997). Jednak najsilniejsza odpowiedź zawsze powoduje substancja alarmowa własnego gatunku (SCHUTZ 1956, PfEIFFER 1963). Zdolność do odbioru i reagowania na substancje alarmowe osobników własnego i obcego gatunku pozwala na plastyczność w odpowiedziach antydrapieżniczych. Rozpoznawanie różnych substancji alarmowych, czyli zarówno swojej, jak i obcej, dostarcza ofiarom więcej informacji na temat ryzyka drapieżnictwa. Dzięki dobrze rozwiniętemu systemowi alarmowemu ryby przeżywają ok. 40\% dłużej (MATHIS i SMITH 1993a). Osobniki danego gatunku moga się z powodzeniem nauczyć odpowiedzi na substancje alarmowe odległych filogenetycznie gatunków, ponieważ wiele ofiar, często reprezentujących tę samą gildię ekologiczna występuje razem i przebywa $\mathrm{w}$ otoczeniu tych samych drapieżników (CHIVERS i SMITH 1998, SMiтH 1999). Na przykład ciernik Gasterosteus aculeatus i strzebla grubogłowa Pimephales promelas sa filogenetycznie odległymi gatunkami ryb, które wzajemnie reaguja na swoje substancje alarmowe. Oba gatunki powszechnie współwystępuja oraz zmagaja się $z$ podobnymi drapieżnikami, dlatego wykrywanie swojej i obcej substancji alarmowej przynosi korzyści każdemu $z$ nich (CHIVERs i SMith 1998). Ryby maja zdolność powiązania ryzyka drapieżnictwa $z$ substancjami alarmowymi pochodzacymi od osobników obcego gatunku (CHIVERs i SMITH 1994). Jedne $z$ badań wykazały, że strzeble potokowe ucza się kojarzenia substancji alarmowych własnego gatunku $z$ substancjami alarmowymi obcego gatunku zawartych jednocześnie w fekaliach ryby drapieżnej - okonia żółtego Perca flavescens (MIRza i CHIVERS 2001). Ryby często uczą się też kojarzyć obraz (bodźce wzrokowe) $z$ zapachem i potem reaguja już na sam zapach (WYATT 2003, POLLOCK i CHIVERS 2004).

\section{ZŁOŻONOŚĆ BUDOWY I FUNKCJI SUBSTANCJI ALARMOWYCH}

Substancja alarmowa to zwiazek złożony $z$ wielu składników, zazwyczaj $z$ jednym dominujacym komponentem o ściśle określonych proporcjach (WYATT 2009). Wstępne badania zawęziły skład chemiczny substancji alarmowej do puryn albo pteryn, związków o małej masie cząsteczkowej (HütTEL 1941). Późniejsze testy laboratoryjne i terenowe wykazały, że substancja aktywna zawarta w substancji alarmowej to 3(N)-tlenek hipoksantyny (Ryc. 3) (BROwN i współaut. 2000). Badania wykonane przez MATHURU i współaut. (2012) na danio pręgowanym Danio rerio w celu poznania dokładnego składu chemicznego substancji alarmowej unaoczniły, 
<smiles>O=c1[nH]c[n+]([O-])c2[nH]cnc12</smiles>

B)

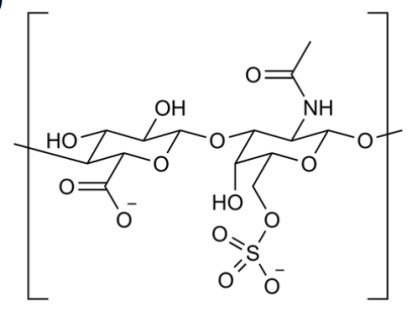

Ryc. 3. Główne składniki substancji alarmowej A. 3(N)-tlenek hipoksantyny, B. siarczan chondroityny.

że substancja alarmowa to mieszanina wielu składników, a substancję aktywną odpowiedzialna za reakcje przerażenia u ryb może stanowić nie tylko 3(N)-tlenek hipoksantyny. Jednym ze składników substancji alarmowej jest siarczan chondroityny (Ryc. 3) - cukier $z$ grupy glikozaminoglikanów (GAG). Gdy ryba ulega zranieniu, jej ciało rozpoczyna syntezę enzymów, które rozkładaja skórę bogata $\mathrm{w}$ siarczan chondroityny. Wówczas następuje rozpad tego cukru na poszczególne fragmenty, powodując reakcję lękową.

Co ciekawe, substancja alarmowa pełni u ryb dwojaka funkcję. Oprócz stymulowania neuronów w celu uniknięcia spotkania $z$ drapieżnikiem, stanowi naturalna barierę antypatogenną. Komórki typu club cells pełnia dodatkowa rolę jako jeden $z$ integralnych elementów układu immunologicznego. Warstwa epidermalna skóry stanowi u ryb pierwsza linię obrony przed uszkodzeniem tkanek przez promieniowanie ultrafioletowe, patogeny, pasożyty, wtórne zakażenia bakteryjne czy różne obrażenia (SMITH 1992, CHIVERs i współaut. 2007, HALBGEWACHS i współaut. 2009). Prawdopodobnie reakcja strachu na substancję alarmowa wydzielana przez te wyspecjalizowane komórki ewoluowała w późniejszym okresie, a pierwszorzędnym celem miała być obrona immunologiczna (JESUTHASAN i MATHURU 2008). Warto zwrócić uwagę, że produkcja substancji alarmowej, poza ewentualna obrona immunologiczna, nie przynosi korzyści pojedynczemu osobnikowi, ale prawdopodobnie jest ważna dla przekazania własnych genów i przetrwania gatunku. W tym kontekście, rozwój i utrzymanie komórek substancji alarmowej może być traktowane jako przejaw zwierzęcego altruizmu, kształtowanego przez dobór krewniaczy, czyli proces, w którym faworyzowanie danego typu zachowania ma korzystny wpływ na przeżywalność bliskich krewnych, w tym potomstwa, a także osobników niespokrewnionych $\mathrm{w}$ linii prostej. W zwiazku $\mathrm{Z}$ tym wzrasta dostosowanie pośrednie nadawcy substancji alarmowej (KREBS i DAVIES 2001).

\section{REAKCJE BEHAWIORALNE INDUKOWANE PRZEZ SUBSTANCJE ALARMOWE}

Wykrywanie chemicznych sygnałów wskazujących na obecność drapieżnika, podobnie jak zasobów pokarmowych, jest kluczowym elementem kształtujacym behawior wielu gatunków zwierząt w ekosystemach wodnych (JERMACZ i współaut. 2017). Ryby doskonałokostne (Teleostei) można podzielić na otwartopęcherzowe (Ostariophysi), czyli posiadające pęcherz pławny połączony $z$ przewodem pokarmowym, i zamkniętopęcherzowe (ang. non-Ostariophysi), majace pęcherz pławny niepołączony $z$ przewodem pokarmowym (NowICKI 1880, PFEIFFER 1963). Do otwartopęcherzowych zalicza się karpiokształtne. Z kolei do zamkniętopęcherzowych przyporządkowuje się m.in. łososiokształtne czy okoniokształtne (PFEIFFER 1963). Warto zauważyć, że cechą większości ryb otwartopęcherzowych jest obecność w naskórku komórek typu club cells, co doprowadziło do stwierdzenia, że tylko ta grupa ryb produkuje i reaguje na uwolnione substancje alarmowe (SMITH 1992, JACHNER 1999). Badania potwierdziły jednak, że nie jest to domena tylko tych ryb, ponieważ komórki te zidentyfikowano także w warstwie epidermalnej ryb zamkniętopęcherzowych (SMITH 1992, BARRETO i współaut. 2014). Ponadto w wielu badaniach wykazano silne reakcje alarmowe na chemiczne zwiazki od osobników własnego gatunku u ryb zamkniętopęcherzowych, np. ciernika, pstraga tęczowego Oncorhynchus mykiss, babki Asterropteryx semipunctata, sandacza amerykańskiego Sander vitreus (CHIVERS i SMITH 1998, FERRARI i współaut. 2010), gupika Poecilia reticulata, głowacza Cottus cognatus, medaki (ryżanki japońskiej) Oryzias latipes (MATHURU 2016). Udokumentowano również reakcję alarmową między zamnknięto- a otwartopeccherzowymi gatunkami ryb. Na przykład jedna $Z$ ryb okoniokształtnych, bass słoneczny Lepomis gibbosus, wykazuje antydrapieżnicza odpowiedź po ekspozycji na 3(N)-tlenek hipoksantyny, głównego składnika substancji alarmowej ryb należących do otwartopeccherzowych (GOLUB i współaut. 2005).

Substancje alarmowe ryb, jak wspomniano, nie sa specyficzne gatunkowo i zazwyczaj indukuja też reakcje alarmowe u różnych gatunków (SMITH 1982). Podobieństwo reakcji u ryb na substancję alarmowa pochodząca od osobników własnego i obcego gatunku prowadzi do kontrowersji dotyczacej tego, czy substancje alarmowe u ryb powin- 
ny być ściśle sklasyfikowane jako feromony (substancje o działaniu wewnatrzgatunkowym) czy jako substancje allelochemiczne mające działanie międzygatunkowe (BURNARD i współaut. 2008). Nadal jest to przedmiotem dyskusji (MAGURRAN i współaut. 1996, CHUNG-DAVIDSON i współaut. 2010).

W odpowiedzi na wykryta substancje alarmowa, niektóre gatunki podpływaja $\mathrm{ku}$ powierzchni wody celem wyskoczenia $z$ niej, podczas gdy inne kierują się w kierunku dna, gdzie staraja się utworzyć zwarta ławicę (SCHUTZ 1956) albo nieruchomieja (LAWRENCE i SMITH 1989). Jeszcze inne pływaja nerwowo przy dnie $Z$ sylwetka pochylona $w$ dół (SMiTH 1977). Generalnie, typowymi reakcjami behawioralnymi w sytuacji ekspozycji ryb-ofiar na substancję alarmowa od zranionych osobników są: ucieczka, poszukiwanie schronienia, redukcja aktywności ruchowej, zaprzestanie żerowania, skupianie się w ławice, znieruchomienie (MATHIS i SMITH 1993b, JACHNER 1999, KOPACK i współaut. 2015) czy opadanie na dno (STODDART 1980, BROWN i współaut. 2001a). Reakcja behawioralna ryb na substancję alarmowa przebiega dwufazowo. W pierwszej fazie ryby zwarte w ławicę uciekaja $w$ popłochu $z$ zagrożonego miejsca, przy czym w ucieczce tej wykonuja dynamiczne i chaotyczne zmiany kierunku ruchu. Druga faza to redukcja aktywności, aż do bezruchu przy dnie bąź w bezpiecznej kryjówce (SMiTH 1992). Przed wykryciem substancji alarmowej ryby wykonuja spokojne ruchy, pływają samotnie bąź w grupie zarówno w toni wodnej, jak i przy dnie (JACHNER 1996). Von Frisch wyróżnił siedem różnych intensywności w reakcji alarmowej, od najbardziej intensywnej, w której ryby pospiesznie uciekaja, aż do ledwie widocznej odpowiedzi behawioralnej (PFEIFFER 1963).

Reakcje behawioralne na uwolnione substancje alarmowe odnotowano u wielu gatunków ryb. Należy zaznaczyć, że reakcje te moga się różnić w zależności od przynależności gatunkowej, stężenia substancji alarmowej, presji drapieżniczej, wieku, płci, stanu sytości czy innych czynników związanych $z$ sama biologia gatunku albo procesem uczenia się. Odpowiedź behawioralna w kontekście substancji alarmowej obserwuje się przede wszystkim u ryb społecznych i niedrapieżnych (JESUTHASAN i MATHURU 2008). Ryby znajdujace się w zasięgu oddziaływania substancji alarmowej pochodzącej od osobników własnego gatunku wykazują wyraźne unikanie tych obszarów (FRIESEN i CHIVERS 2006). Różne stężenia substancji alarmowej powoduja odmienne reakcje strachu, generalnie - niskie stężenia wywołuja nadpobudliwa i chaotyczna aktywność lokomotoryczna, podczas gdy wy- sokie stężenia sa przyczyna znieruchomienia (LAWRENCE i SMITH 1989, MATHURU i współaut. 2012). Warto podkreślić, że ryby pochodzace $z$ populacji żyjacych w środowisku o dużym nasileniu presji drapieżniczej reagują mniej panicznie na uwolniona substancję alarmowa niż osobniki $z$ miejsc o mniejszej presji (JACHNER 1999). Natomiast ryby we wczesnych etapach rozwoju nie wykazuja reakcji na substancję alarmowa i nie maja komórek typu club cells. Zdolność do reagowania na substancje alarmowe i rozwój komórek produkujacych te substancje rozpoczyna się przeciętnie po 30 dniach życia (SMITH 1977). Należy zaznaczyć jednak, że samce sezonowo traca swoje komórki odpowiedzialne za wydzielanie substancji alarmowej na czas tarła w odpowiedzi na wzrost poziomu androgenów (SMITH 1973). Z kolei głodne ryby przestaja reagować na substancję alarmowa.. Ich motywacja skupiona na wyszukaniu pożywienia jest na tyle duża, że nie zważaja na żadne okoliczności, nawet takie jak atakujacy w sąsiedztwie drapieżnik (BROWN i SMith 1996, JESUTHASAN i MATHURU 2008). Być może zmysł węchu u głodnych ofiar jest zbyt osłabiony. Ponadto ryby babkowate, które sa głodzone przez dłuższy czas, przestaja wytwarzać komórki odpowiedzialne za produkcję substancji alarmowej, co jest kompromisem energetycznym między żerowaniem a behawiorem antydrapieżniczym i zwiąanymi $z$ nim wszelkimi kosztami (MCCORMICK i LARSON 2008). Natomiast ryby takie jak szczupak Esox lucius, znane $z$ żerowania na rybach karpiowatych, potrzebuja swiatła do lokalizacji swojej ewentualnej zdobyczy. Szczupak kieruje się wzrokiem podczas polowania na swoje ofiary $z$ zasadzki. W zwiazku $z$ tym jego ofiary nie reaguja na substancje alarmowa w nocy, bo nie istnieje realne niebezpieczeństwo drapieżnictwa (JACHNER 1999). Długość czasu spędzonego na odbieraniu informacji chemicznych tłumaczy prosta korelacja - im wyższa koncentracja substancji alarmowej $\mathrm{w}$ wodzie, tym dłuższy czas spędzony na nerwowym i nieregularnym pływaniu lub bezruchu na dnie zbiornika $z$ powodu bliskości drapieżnika (WALDMAN 1982, SPEedie i Gerlai 2008). U wielu gatunków ryb reakcja alarmowa trwa ok. 10 minut (MATHURU 2016). Powrót do typowego behawioru trwa dłużej, jeśli ryba jest izolowana od innych osobników (JESUTHASAN i MATHURU 2008). Odpowiedzi na substancje alarmowe nie musza się przejawiać tylko jako zmiany behawioralne i moga być obecne tylko na poziomie fizjologicznym - zmiany stężenia glukozy w osoczu, bradykardia (PFEIFFER i LAMOUR 1976, REHNBERG i SCHRECK 1987, REHNBERG i współaut. 1987) czy tempo zużycia tlenu (HUUSKONEN i KAR- 
JALAINEN 1997, PAUL i współaut. 2018). Ekspozycja ryb na substancję alarmowa jest stresujacym wydarzeniem dla nich, czego dowodzi wzrost poziomu hormonu stresu (kortyzolu) u medaki (MATHURU 2016).

\section{STEŻENIE I CZAS AKTYWNOŚCI BIOLOGICZNEJ SUBSTANCJI ALARMOWYCH}

Substancje alarmowe sa efektywne przy bardzo niskich koncentracjach (SMITH 1985, MATHIS i SMiTH 1992, Døving i współaut. 2005). Ekstrakt ze skóry mniej rozcieńczony powoduje silniejsza reakcje (PFEIFFER 1963). W jednym $z$ badań eksponowano ławicę strzebli grubogłowej na 3(N)-tlenek hipoksantyny o stężeniach od 0,1 do 6,7 nM. Odpowiedź behawioralna miała miejsce przy stężeniach 0,4 nM i wyższych (BROwN i współaut. 2001b). Natomiast eksperymenty prowadzone przez MATHIS i SMITHA (1992) na strzebli grubogłowej wykazały, że gąbka nasaczona substancją alarmowa tego gatunku i umieszczona w środowisku naturalnym ewidentnie przyczyniła się do istotnego zmniejszenia połowów ryb $\mathrm{w}$ miejscu prowadzenia badań. Strzeble unikały obszarów z substancjac alarmowa pomimo tak dużego jej rozcieńczenia. Uszkodzona skóra strzebli grubogłowej wywołuje behawioralna reakcję u osobników własnego gatunku już przy umieszczeniu $1 \mathrm{~cm}^{2}$ skóry zawierajacej komórki $z$ substancja alarmowa w objętości 580001 wody (LAWRENCE i SMITH 1989), co jest porównywalne $z$ objętością kuli o promieniu 2,4 $\mathrm{m}$ albo objętościa cylindra o wysokości $1 \mathrm{~m}$ i promieniu 4,3 $\mathrm{m}$ (WISENDEN 2015). Jeszcze inne badania dostarczaja informacji o tym, że przestrzeń aktywowana przez substancję alarmowa jest stosunkowo duża. Tylko $2 \mathrm{~cm}^{2}$ skóry wystarcza, aby wpłynać na ryby znajdujace się w odległości $2 \mathrm{~m}$ od źródła substancji alarmowej (WISENDEN 2008). Koncentracja substancji alarmowej dostarcza informacji ofiarom o odległości od żerującego drapieżnika. W zwiąku z tym niższe stężenia wskazują, że drapieżnik stanowi mniejsze zagrożenie (JACHNER 1996, LÖNNSTEDT i MCCORMICK 2011).

Czas aktywności biologicznej substancji alarmowej zależy od degradacji biochemicznej prowadzonej przez mikroorganizmy, składników chemicznych obecnych w skórze ryby, ruchów mas wody (WISENDEN i współaut. 2009) czy promieniowania słonecznego powodującego fotodegradacje substancji alarmowej (CHIVERS i współaut. 2013). Przykładowo, odpowiedzi behawioralne strzebli grubogłowej na świeżo zsyntetyzowany ekstrakt ze skóry były takie same, jak na ekstrakt ze skóry podany po $3 \mathrm{~h}$ od jego syntezy w tempera- turze $18^{\circ} \mathrm{C}$. $\mathrm{Z}$ kolei po upływie $6 \mathrm{~h}$ od uwolnienia substancji alarmowej $\mathrm{w} 18^{\circ} \mathrm{C}$ osobniki strzebli grubogłowej reagowały dużo słabiej (WISENDEN i współaut. 2009). Zatem czas aktywności tej substancji w środowisku w temperaturze $18^{\circ} \mathrm{C}$ waha się od 3 do 6 godzin.

\section{PODSUMOWANIE}

W środowisku wodnym komunikacja chemiczna wydaje się być szczególnie ważna ze względu na to, że substancje alarmowe moga być przenoszone na duże odległości. Poza tym daje rybom możliwość odbioru informacji (zwłaszcza dotyczących aktywnie żerującego drapieżnika) bez względu na ograniczenia środowiska wodnego.

Należy jednak pamiętać, że same substancje alarmowe nie sa sygnałami niezawodnie informujacymi potencjalną ofiare o grożącym niebezpieczeństwie - nie sa bowiem jedynymi sygnałami świadczacymi o ryzyku drapieżnictwa. Nieprawidłowa identyfikacja ryzyka drapieżnictwa może być odpowiedzialna za nieskuteczna strategię obronna (ÅBJÖRNSSON i współaut. 2004). Wysokie koszty zachowań antydrapieżniczych dotycza nieprawidłowych reakcji ofiar wobec osobników, które nie sa drapieżnikami lub sa nieaktywnymi drapieżnikami. To powoduje stratę czasu i energii, które w przeciwnym razie byłyby przeznaczone na żerowanie i rozmnażanie (LIMA i Dill 1990). Właśnie dlatego właściwa ocena ryzyka drapieżnictwa przy użyciu wszystkich dostępnych zwiazków chemicznych wskazujących na obecność drapieżnika, jego kondycję i prawdopodobieństwo ataku, ma kluczowe znaczenie dla ofiar. Ryby zdolne do precyzyjnej interpretacji stopnia zagrożenia ze strony drapieżnika przez sygnały chemiczne, nie traca czasu $\dot{i}$ energii na zbędne uruchamianie mechanizmów obronnych (JACHNER 1999). Nawet najefektywniejsza obrona traci sens, jeżeli koszty energetyczne wynikajace $z$ jej korzystania przewyższają zyski - uniknięcie drapieżnika (RUTKOWSKI 1999).

Streszczenie

Gatunki ryb stanowiace ofiary w łańcuchu pokarmowym sa zdolne do oceny ryzyka spotkania drapieżnika, kierując się dostępnymi sygnałami (chemiczne, wzrokowe, elektryczne albo mechaniczne) w środowisku. Jednak woda nie jest dobrym nośnikiem dla większości sygnałów $z$ powodu stosunkowo małej przejrzystości i dużej gęstości ośrodka. Sygnalizacja chemiczna daje rybom możliwość przeciwstawienia się tym ograniczeniom i stąd ma pierwszorzędne znaczenie. Substancje alarmowe uwalniane $\mathrm{z}$ uszkodzonych komórek naskórka ryb-ofiar po ataku drapieżnika stanowia sygnał ostrzegawczy dla innych ofiar o zagrożeniu ze strony drapieżników. Informacje te wywołuja powszechną reakcję wśród potencjalnych ofiar, w tym u osobników obcego gatunku, które sa w stanie wykryć żerującego drapieżnika i zminima- 
lizować ryzyko związane $z$ jego spotkaniem. Szansa na wykorzystanie substancji alarmowych od osobników obcego gatunku wzrasta, gdy gatunki sa blisko spokrewnione ze soba i/lub współwystępuja oraz przebywaja z tymi samymi drapieżnikami w ekosystemie.

\section{LITERATURA}

ÅBJÖRNSSON K., HANSSON L.-A., BRÖNMARK C. 2004. Responses of prey from habitats with different predator regimes: local adaptation and heritability. Ecology 85, 1859-1866.

ADLER F. R., HARWELl C. D., 1990. Inducible defenses, phenotypic variability and biotic environments. Trends Ecol. Evol. 5, 407-410.

ANTKIEWICZ M. M., DZIURDZIA A., SochAJ A., MikA M., 2008. Feromony - unikalny język świata przyrody. Kosmos 57, 127-134.

BARRETO R. E., BARBOSA-JÚNIOR A., URBINATI E. C., HofFmanN A., 2014. Cortisol influences the antipredator behavior induced by chemical alarm cues in the Frillfin goby. Horm. Behav. 65, 394-400.

BRown G. E., SMith R. J. F., 1996. Foraging trade-offs in fathead minnows (Pimephales promelas, Osteichthyes, Cyprinidae): acquired predator recognition in the absence of an alarm response. Ethology 102, 776-785.

BRown G. E., GodIN J.-G. J., 1997. Anti-predator responses to conspecific and heterospecific skin extracts by threespine sticklebacks: alarm pheromones revisited. Behaviour 134, 11231134.

BRown G. E., AdRian J. C., JR., SMYTH E., LEET H., BRENNAN S., 2000. Ostariophysan alarm pheromones: laboratory and field tests of the functional significance of nitrogen oxides. J. Chem. Ecol. 26, 139-154.

Brown G. E., ADRIAN J. C., JR., PATton T., ChIVERS D. P., 2001a. Fathead minnows learn to recognize predator odour when exposed to concentrations of artificial alarm pheromone below their behavioural-response threshold. Can. J. Zool. 79, 2239-2245.

BRown G. E., ADRIAN J. C. JR., SHIH M. L., 2001b. Behavioural responses of fathead minnows to hypoxanthine-3- $N$-oxide at varying concentrations. J. Fish Biol. 58, 1465-1470.

BRÖNMARK C., HANSSON L. -A, 2000. Chemical communication in aquatic systems: an introduction. Oikos 88, 103-109.

BURNARD D., GOZLAN R. E., GRIFFITHS S. W., 2008. The role of pheromones in freshwater fishes. J. Fish Biol. 73, 1-16.

ButENANDT A., BECKMANN R., STAMM D., HECKER E., 1959. Über den Sexuallockstoff des Seidenspinners Bombyx mori. Reindarstellung und Konstitutionsermittlung. Z. Naturforsch. B $14,283-284$

Chivers D. P., SMith R. J. F., 1994. Fathead minnows, Pimephales promelas, acquire predator recognition when alarm substance is associated with the sight of unfamiliar fish. Anim. Behav. 48, 597-605.

ChIVERS D. P., SMith R. J. F., 1998. Chemical alarm signalling in aquatic predator-prey systems: a review and prospectus. Ecoscience 5, 338-352

ChIVERS D. P., BRown G. E., SMith R. J. F. 1995a. Acquired recognition of chemical stimuli from pike, Esox lucius, by brook sticklebacks, Culaea inconstans (Osteichthyes, Gasterosteidae). Ethology 99, 234-242.

Chivers D. P., Wisenden B. D., SMith R. J. F., 1995b. The role of experience in the response of fathead minnows (Pimephales promelas) to skin extract of Iowa darters (Etheostoma exile). Behaviour 132, 665-674.

Chivers D. P., Wisenden B. D., Hindman C. J., MichalaK T. A., KusCh R. C., KaminsKYJ S. G. W., JACK K. L., FERRARI M. C. O., POllOCK R. J., HalbGewachs C. F., Pollock M. S., AleMADI S. i współaut., 2007. Epidermal „alarm substance" cells of fishes maintained by non-alarm functions: possible defence against pathogens, parasites and UVB radiation. P. Roy. Soc. B-Biol. Sci. 274, 2611-2619.

Chivers D. P., DiXson D. L., White J. R., MCCoRmicK M. I., FERRARI M. C. O., 2013. Degradation of chemical alarm cues and assessment of risk throughout the day. Ecol. Evol. 3, 3925-3934.

Chung-Davidson Y.-W., Huertas M., Li W., 2010. A review of research in fish pheromones. [W:] Chemical Communication in Crustaceans. BREITHAUPT T., THIEL M. (red.). Springer-Verlag, New York, 467-482.

Clinchy M., SHERIFF M. J., ZANETTE L. Y., 2013. Predator-induced stress and the ecology of fear. Funct. Ecol. 27, 56-65.

CRAMPTON W. G. R., 2019. Electroreception, electrogenesis and electric signal evolution. J. Fish Biol. 95, 92-134.

Døving K. B., Hamdani E. H., HÖGLund E., KaSUMYAN A., TUVIKENE A. O., 2005. Review of the chemical and physiological basis of alarm reactions in cyprinids. [W:] Fish Chemosenses. REuTTER K., KAPOOR B. G. (red.). Science Publishers, Inc., New Hampshire, Plymouth, 133-163.

FERRARI M. C. O., Wisenden B. D., Chivers D. P., 2010. Chemical ecology of predator-prey interactions in aquatic ecosystems: a review and prospectus. Can. J. Zool. 88, 698-724.

FRIESEN R. G., ChIVERS D. P., 2006. Underwater video reveals strong avoidance of chemical alarm cues by prey fishes. Ethology 112, 339-345.

GLIWICZ M. Z., 1986. Predation and the evolution of vertical migration in zooplankton. Nature 320, 746-748.

GoluB J. L., VERMETTE V., BROWN G. E., 2005. Response to conspecific and heterospecific alarm cues by pumpkinseeds in simple and complex habitats: field verification of an ontogenetic shift. J. Fish Biol. 66, 1073-1081.

HalbGewachs C. F., Marchant T. A., Kusch R. C., ChIVers D. P., 2009. Epidermal club cells and the innate immune system of minnows. Biol. J. Linn. Soc. 98, 891-897.

HAMDANI E. H., Døving K. B., 2003. Sensitivity and selectivity of neurons in the medial region of the olfactory bulb to skin extract from conspecifics in crucian carp, Carassius carassius. Chem. Senses 28, 181-189.

Hamdani E. H., StaBell O. B., Alexander G. DøVING K. B., 2000. Alarm reaction in the crucian carp is mediated by the medial bundle of the medial olfactory tract. Chem. Senses 25, 103-109.

HARA T. J., 1994. Olfaction and gustation in fish: an overview. Acta Physiol. Scand. 152, 207217

HEIL M., 2009. Plant communication. [W:] Encyclopedia of Life Sciences. John Wiley \& Sons, Ltd, Chichester, UK, 1-6.

HUUSKONEN H., KARJALAINEN J., 1997. Predator-induced respiratory responses in juveniles of vendace Coregonus albula, whitefish C. lavaretus, perch Perca fluviatilis and roach Rutilus rutilus. Environ. Biol. Fish. 49, 265-269. 
HÜTTEL R., 1941. Die chemische Untersuchung des Schreckstoffes aus Elritzenhaut. Die Naturwissenschaften 29, 333-334.

JACHNER A., 1996. Alarm reaction in bleak (Alburnus alburnus (L.), Cyprinidae) in response to chemical stimuli from injured conspecifics. Hydrobiologia 325, 151-155.

JACHNER A., 1999. Indukowane przez drapieżce mechanizmy obronne u ryb. Kosmos 48, 491500.

JERMACZ Ł., DZIERŻYŃSKA-BIAŁOŃCZYK A., KOBAK J., 2017. Predator diet, origin or both? Factors determining responses of omnivorous amphipods to predation cues. Hydrobiologia 785 , 173-184.

Jesuthasan S. J., Mathuru A. S., 2008. The alarm response in zebrafish: innate fear in a vertebrate genetic model. J. Neurogenet. 22, 211-228.

KARLSON P., LÜSCHER M., 1959. „Pheromones”: a new term for a class of biologically active substances. Nature 183, 55-56.

KATKOWSKA M. J., 2013. Wpływ wybranych czynników środowiska na behawior organizmów żywych. [W:] Skrypt do ćwiczeń z toksykologii $i$ ekotoksykologii dla studentów Ochrony Srodowiska. TEGGOWSKA E., WOSIŃSKA A. (red.). Wydawnictwo Naukowe Uniwersytetu Mikołaja Kopernika, Toruń, 93-103.

KeEnleyside M. H. A., 1979. Diversity and adaptation in fish behaviour. Springer-Verlag, Berlin, Heidelberg.

KoKOCIŃSKA A., KALETA T., 2015. Behawioryzm $i$ behawior - myśl filozoficzna $i$ badania przyrodnicze. Kosmos 64, 221-227.

KopACK C. J., BRODER E. D., LEPAK J. M., FETHERMAN E. R., ANGELONI L. M., 2015. Behavioral responses of a highly domesticated, predator naive rainbow trout to chemical cues of predation. Fish. Res. 169, 1-7.

KREBS J. R., DAVIES N. B., 2001. Wprowadzenie do ekologii behawioralnej. Wydawnictwo $\mathrm{Na}-$ ukowe PWN, Warszawa.

KULCZYCKI E., 2012. Teoretyzowanie komunikacji. Wydawnictwo Naukowe Instytutu Filozofii UAM, Poznań.

LAWRENCE B. J., SMITH R. J. F., 1989. Behavioral responses of solitary fathead minnow, Pimephales promelas, to alarm substance. J. Chem. Ecol. 15, 209-219.

LILEY N. R., 1982. Chemical communication in fish. Can. J. Fish Aquat. Sci. 39, 22-35.

LimA S. L., Dill L. M., 1990. Behavioral decisions made under the risk of predation: a review and prospectus. Can. J. Zool. 68, 619-640.

LÖNNSTEDT O. M., MCCORMICK M. I., 2011. Chemical alarm cues inform prey of predation threat: the importance of ontogeny and concentration in a coral reef fish. Anim. Behav. 82, 213-218.

MagurRan A. E., IRving P. W., Henderson P. A., 1996. Is there a fish alarm pheromone? A wild study and critique. P. Roy. Soc. Lond. B Bio. 263, 1551-1556.

MATEJCZYK M., SUCHOWIERSKA M., 2011. Charakterystyka zjawiska quorum sensing i jego znaczenie $w$ aspekcie formowania $i$ funkcjonowania biofilmu $w$ inżynierii środowiska, budownictwie, medycynie oraz gospodarstwie domowym. Budownictwo i Inżynieria Środowiska $2,71-75$.

Mathis A., SMITH R. J. F., 1992. Avoidance of areas marked with chemical alarm substance by fathead minnows (Pimephales promelas) in a natural habitat. Can. J. Zool. 70, 14731476.
Mathis A., Smith R. J. F., 1993a. Chemical alarm signals increase the survival time of fathead minnows (Pimephales promelas) during encounters with northern pike (Esox lucius). Behav. Ecol. 4, 260-265.

MATHIS A., SMITH R. J. F., 1993b. Intraspecific and cross-superorder responses to chemical alarm signals by brook stickleback. Ecology $74,2395-2404$.

MATHURU A. S., 2016. Conspecific injury raises an alarm in medaka. Sci. Rep. 6, 1-8.

Mathuru A. S., Kibat C., Cheong W. F., Shui G., WENK M. R., FRIEDRICH R. W., JESUTHASAN S., 2012. Chondroitin fragments are odorants that trigger fear behavior in fish. Curr. Biol. 22, 538-544.

MCCORMICK M. I., LARSON J. K., 2008. Effect of hunger on the response to, and the production of, chemical alarm cues in a coral reef fish. Anim. Behav. 75, 1973-1980.

MiRZA R. S., ChIVERS D. P., 2001. Learned recognition of heterospecific alarm signals: the importance of a mixed predator diet. Ethology 107, 1007-1018.

NELSON J. S., 1984. Fishes of the world. John Wiley \& Sons, Inc., New York/Chichester/ Brisbane/Toronto/Singapore.

NORDELL S. E., 1998. The response of female guppies, Poecilia reticulata, to chemical stimuli from injured conspecifics. Environ. Biol. Fish. $51,331-338$.

NOWICKI M., 1880. Ryby $i$ wody Galicyi, pod wzgledem rybactwa krajowego. Drukarnia W. Korneckiego, Kraków.

Paul N., Novais S. C., Lemos M. F. L., KunzmanN A., 2018. Chemical predator signals induce metabolic suppression in rock goby (Gobius paganellus). Plos One 13, 1-13.

PFEIFFER W., 1963. Alarm substances. Experientia $19,113-123$.

PFEIFFER W., 1977. The distribution of fright reaction and alarm substance cells in fishes. Copeia $1977,653-665$.

PFEIFFER W., LAMOUR D., 1976. Effect of alarm substance on the heart rate in Phoxinus phoxinus (L.) (Cyprinidae, Ostariophysi, Pisces). Rev. Suisse Zool. 83, 861-873.

PIJANOWSKA J., 1999. Warunki faworyzujace plastyczność reakcji obronnych. Kosmos 48, 435440.

POllock M. S., Chivers D. P., 2004. The effects of density on the learned recognition of heterospecific alarm cues. Ethology 110, 341-349.

REHNBERG B. G., SCHRECK C. B., 1987. Chemosensory detection of predators by coho salmon (Oncorhynchus kisutch): behavioural reaction and the physiological stress response. Can. J. Zool. 65, 481-485.

RehnBerg B. G., SMith R. J. F., Sloley B. D., 1987. The reaction of pearl dace (Pisces, Cyprinidae) to alarm substance: time-course of behavior, brain amines, and stress physiology. Can. J. Zool. 65, 2916-2921.

REK P., 2010. Komunikacja $i$ sygnalizacja zwierzat. Kosmos 59, 459-466.

RUTKOWSKI D. H., 1999. Mechanizmy obrony przed drapieżnictwem u bezkręgowców litoralnych. Kosmos 48, 509-518.

SCHUTZ F., 1956. Vergleichende Untersuchungen über die Schreckreaktion bei Fischen und deren Verbreitung. J. Comp. Physiol. A 38, 84135.

SiH A., 1987. Predators and prey lifestyles: an evolutionary and ecological overview. [W:] Predation: Direct and Indirect Impacts on Aquatic Communities. KERFOOT W. C., SIH A. (red.). 
University Press of New England, Hanover, New Hampshire, 203-224.

SiH A., Wooster D. E., 1994. Prey behavior, prey dispersal, and predator impacts on stream prey. Ecology 75, 1199-1207.

SMITH R. J. F., 1973. Testosterone eliminates alarm substance in male fathead minnows. Can. J. Zool. 51, 875-876.

SMITH R. J. F., 1977. Chemical communication as adaptation: alarm substance of fish. [W:] Chemical Signals in Vertebrates. MÜLLER-SCHWARZE D., MOZELl M. M. (red.). Springer, Boston, MA, 303-320.

SMITH R. J. F., 1982. Reaction of Percina nigrofasciata, Ammocrypta beani, and Etheostoma swaini (Percidae, Pisces) to conspecific and intergeneric skin extracts. Can. J. Zool. 60, 1067-1072.

SMiTH R. J. F., 1985. Chemical information. [W:] The Control of Fish Migration. Springer, Berlin, Heidelberg, 65-118.

SMITH R. J. F., 1992. Alarm signals in fishes. Rev. Fish Biol. Fisher. 2, 33-63.

SMITH R. J. F., 1999. What good is smelly stuff in the skin? Cross function and cross taxa effects in fish „alarm substances”. [W:] Advances in Chemical Signals in Vertebrates. JOHNSTON R. E., MÜller-Schwarze D., SORENSEN P. W. (red.). Springer US, Boston, MA, 475487.

SPEEDIE N., GERLAI R., 2008. Alarm substance in duced behavioral responses in zebrafish (Danio rerio). Behav. Brain Res. 188, 168-177.

STODDART D. M., 1980. Alarm and defence. [W: The Ecology of Vertebrate Olfaction. Springer, Netherlands, 161-181.

TROJAN M., 2013. Na tropie zwierzęcego umysłu. Wydawnictwo Naukowe Scholar, Warszawa.

VON FRISCH K., 1938. Zur Psychologie des Fisch-Schwarmes. Die Naturwissenschaften 26, 601-606.

VON FRISCH K., 1941. Die Bedeutung des Geruchsinnes im Leben der Fische. Die Naturwissenschaften 29, 321-333.
WALDMAN B., 1982. Quantitative and developmental analyses of the alarm reaction in the zebra danio, Brachydanio rerio. Copeia 1982, 1-9.

WELDON P. J., 1990. Responses by vertebrates to chemicals from predators. [W:] Chemical Signals in Vertebrates 5. MACDONALD D. W., MÜlleR-SchwARZE D., NATYNCZUK S. E. (red.). Oxford University Press, Oxford, U.K, 500521.

Winans S. C., BAssler B. L., 2008. Chemical communication among bacteria. American Society for Microbiology, Washington, DC.

WISENDEN B. D., 2003. Chemically mediated strategies to counter predation. [W:] Sensory Processing in Aquatic Environments. Collin S. P., MARSHALL N. J. (red.). Springer-Verlag, New York, 236-251.

WiSENDEN B. D., 2008. Active space of chemical alarm cue in natural fish populations. Behaviour 145, 391-407.

WiSENDEN B. D., 2015. Chemical cues that indicate risk of predation. [W:] Fish Pheromones and Related Cues. SORENSEN P. W., WISENDEN B. D. (red.). John Wiley \& Sons, Inc., Ames, Chichester, 131-148.

Wisenden B. D., Chivers D. P., SMith R. J. F., 1994. Risk-sensitive habitat use by brook stickleback (Culaea inconstans) in areas associated with minnow alarm pheromone. J. Chem. Ecol. 20, 2975-2983.

Wisenden B. D., RugG M. L., Korpi N. L., FuseLIER L. C., 2009. Lab and field estimates of active time of chemical alarm cues of a cyprinid fish and an amphipod crustacean. Behaviour 146, 1423-1442.

WyATT T. D., 2003. Pheromones and animal be haviour: communication by smell and taste. Cambridge University Press, Cambridge.

WYATT T. D., 2009. Fifty years of pheromones. Nature 457, 262-263.

KOSMOS Vol. 69, 2, 345-354, 2020

PIOTR KŁOSIŃSKI

Department of Ecology and Biogeography, Faculty of Biological and Veterinary Sciences, Nicolaus Copernicus University, 1 Lwowska Str.,87-100 Toruń,E-mail: peter.klosinski1995@gmail.com

THE MEANING OF ALARM SUBSTANCES IN FISH CHEMICAL COMMUNICATION

Summary

Fish species that are prey in the food chain are able to assess the risk of encountering a predator based on available signals in the environment (chemical, visual, electrical or mechanical). However, water is not a good carrier for most signals due to the relatively low transparency and high density of the medium. Chemical signaling gives fish the opportunity to oppose these restrictions and is therefore of paramount importance. Alert substances released from damaged skin cells of fish-victims after a predator attack are a warning signal to other victims about the threat of predators. This information causes a widespread reaction among potential victims, including individuals of a foreign species that are able to detect a preying predator and minimize the risk associated with its meeting. The chance of using alert substances from individuals of a foreign species increases when the species are closely related to each other and/or coexist and stay with the same predators in the ecosystem. 